\title{
HOW COULD EVERYONE HAVE BEEN SO WRONG? FORECASTING THE GREAT DEPRESSION WITH THE RAILROADS
}

\author{
Adam Klug \\ John S. Landon-Lane \\ Eugene N. White \\ Working Paper 9011 \\ http://www.nber.org/papers/w9011 \\ NATIONAL BUREAU OF ECONOMIC RESEARCH \\ 1050 Massachusetts Avenue \\ Cambridge, MA 02138 \\ June 2002
}

\begin{abstract}
Although he passed away before the paper was completed, Adam Klug provided the initial inspiration for this paper. His enthusiasm, wit and insights are greatly missed. We offer special thanks to Howard Bodenhorn, Carl Bonham, Michael Bordo, and Hugh Rockoff and seminar participants at Rutgers University and the NBER's Summer Institute for the valuable comments. The views expressed herein are those of the authors and not necessarily those of the National Bureau of Economic Research.
\end{abstract}

(C) 2002 by Adam Klug, John S. Landon-Lane and Eugene N. White. All rights reserved. Short sections of text, not to exceed two paragraphs, may be quoted without explicit permission provided that full credit, including $(\mathcal{C}$ notice, is given to the source. 
How Could Everyone Have Been So Wrong?

Forecasting the Great Depression with the Railroads

Adam Klug, John S. Landon-Lane and Eugene N. White

NBER Working Paper No. 9011

June 2002

JEL No. E30, N12

\begin{abstract}
Contemporary observers viewed the recession that began in the summer of 1929 as nothing extraordinary. Recent analyses have shown that the subsequent large deflation was econometrically forecastable, implying that a driving force in the depression was the high expected real interest rates faced by business. Using a neglected data set of forecasts by railroad shippers, we find that business was surprised by the magnitude of the great depression. We show that an ARIMA or Holt-Winters model of railroad shipments would have produced much smaller forecast errors than those indicated by the surveys. The depth and duration of the depression was beyond the experience of business, which appears to have believed that recovery would happen quickly as in previous recessions. This failure to anticipate the collapse of the economy suggests roles for both high real rates of interest and a debt deflation in the propagation of the depression.
\end{abstract}

John Landon-Lane Department of Economics Rutgers University

New Jersey Hall

New Brunswick, NJ 08901

lane@econ.rutgers.edu
Eugene N. White

Department of Economics

Rutgers University

New Jersey Hall

New Brunswick, NJ 08901

and NBER

white@economics.rutgers.edu 
"It seems manifest that thus far the difference between the present comparatively mild business recession and the severe depression of 1920-1921 is like that between a thundershower and a tornado" (May 5, 1930)

"Business showed further gain last week and if improvement continues at the present rate, September should mark the low of the depression." (October 17, 1931)

---Irving Fisher ${ }^{1}$

While some sages claimed to have forecast the collapse of the stock market in 1929, no guru divined the ensuing depression. At the outset, the Great Depression appeared to be an ordinary, though sharp, recession (Friedman and Schwartz, 1963). Most economic indicators had declined almost continuously from August 1929 until the end of 1930. Although consumers and investors seem to have become unusually uncertain after the 1929 stock market crash (Romer, 1990), many businessmen seemed to believe that it would be only a short contraction. In retrospect, this bullishness amazes, as the only relief from decline was an increase in industrial production and personal income in the first quarter of 1931. Mirroring this positive outlook of some business leaders, Irving Fisher of Yale and the forecasters at the Harvard Economic Service remained extraordinarily optimistic two years into the greatest economic recession of the twentieth century. ${ }^{2}$

While the extant evidence shows that professional forecasters failed to predict that the recession would turn into a depression, there is no clear consensus about whether business or the public, in general anticipated it. Much attention has focused on whether the price deflation was predicted. If deflation were anticipated, the falling nominal yields would have coincided with rising real yields, thus helping to explain the collapsing consumption and investment that is emphasized in many explanations of the Great Depression (Brunner, 1981;

\footnotetext{
${ }^{1}$ Quoted in Dominguez, Fair and Shapiro (1988), p. 607.

${ }^{2}$ Dominguez, Fair and Shapiro (1988) found that even if these contemporary forecasters had modern time series methods at their disposal, they would not have been able to predict industrial production or price movements with any greater success.
} 
Cecchetti, 1992; Romer, 1992, 1993). If, on the other hand, the decline in prices was unanticipated, it would have hit the economy by adding to debt burdens, forcing otherwise solvent debtors into bankruptcy and raising risk premiums (Fisher, 1933, Bernanke, 1983, Bernanke and Gertler, 1989, Calomiris, 1993).

Evidence for correctly anticipating the deflation was provided by Cecchetti's (1992) forecasts of prices. He pointed out that changes in the price level were positively correlated in the interwar period, implying that simple rules of thumb would have led to expectations of a continued deflation. Reading the business press, Nelson (1991) concluded that up until mid1930 most observers expected only a mild deflation. Afterwards, they anticipated a much greater deflation, which might move prices back to pre-World War I levels. Romer (1992) found that high ex ante real rates of interest through 1932 were responsible for the collapse of fixed investment and consumer durable spending. ${ }^{3}$ In contrast, Hamilton (1987) argued that the information content of futures markets for commodities showed that the great deflation was largely unanticipated. Modelling the relationship between commodity prices and the aggregate price level, Hamilton (1992) found that for the first year of the depression people only expected one tenth of the total price level decline, while in 1931 and 1932 half the price drops were anticipated. Supporting the view that changes in the price level were unanticipated, Evans and Wachtel (1993) claimed that they were largely unexpected because there was considerable ex ante uncertainty about the future course of prices.

Times series models and futures markets, thus yield very different stories about the public's expectations. Unfortunately, there are no surveys of the price expectations of either the public or business. But, there is one very careful survey that reveals expectations about 
the level of economic activity. This paper uses a long ignored panel of survey data on railroad freight car shipments. The survey data shows that business managers persistently failed to anticipate the collapse of 1929-1933 each step of the way down. This finding is striking because if business managers had forecasted demand from previous actual shipments, using simple rules, their errors would have been much smaller. Likewise, a modern ARIMA model predicts the demand for freight cars significantly better. It appears that business continued to expect the economy to begin a recovery and that the shift in the level of activity took a long time to accept. The magnitude of the collapse appears to have been beyond the public's comprehension, as all recoveries within recent experience had begun after a few quarters. Like the professional forecasters and investors in futures markets, railroad managers failed to forecast the depression, expecting it to follow the pattern of recent recessions. Unexpected policy and economic events fooled both the public and the experts.

\section{Surveying Railroad Shippers}

Surveys of expectations are relatively rare in economics, historical surveys are even rarer. ${ }^{4}$ In this paper we have "rediscovered" the only known survey data concerning macroeconomic events from the Great Depression. Although studied as late as the 1950s and early 1960s, railroad shippers' forecasts were forgotten just as the econometric revolution began.

Coordinating freight cars to move goods across the United States undamaged and on time had always been difficult. In the 1920 s, the problem of freight car allocation alarmed

\footnotetext{
${ }^{3}$ Romer estimated expected real rates of interest, with the embedded expected inflation rates, from the fitted values of a regression of the ex post real commercial paper rates on current and lagged macroeconomic variables plus seasonals.

${ }^{4}$ Lovell (1986) reviewed the few surveys of business forecasts and their implications for theories of expectations.
} 
many shippers who found that they were unable to secure cars in sufficient number in time to keep their shipments on schedule. In response, the Association of American Railroads (AAR) asked shippers to estimate their freight car requirements one quarter in advance. Beginning in 1923, regional Shippers' Advisory Boards were formed under the auspices of the Car Service Division of the AAR (Hultgren, 1955).

The AAR's railroad shippers' forecasts of the demand for freight cars for 32 commodities from 13 regions were produced by Regional Shippers Advisory Boards. These regional boards collected data from business firms' traffic managers. The traffic manager was responsible for arranging and expediting the shipment of a firm's product to purchasers and the receipt of supplies and equipment. With knowledge of the firm's production and shipment schedules, the traffic manager made arrangements with railroads and other carriers. Approximately six weeks before the beginning of the next quarter, the shippers were asked to forecast their freight car requirements for that quarter. The forecasts were compiled two to three weeks later by the regional board and then submitted to the national board and the AAR. The final figures were published just before the beginning of the quarter in a release, the "National Forecast of the Regional Shippers Advisory Boards." One quarter later, these releases reported the actual freight car use, thus providing an easy measure of the error made by these business managers in their forecast of the shipment of goods. According to Ferber (1953), the AAR apparently found these forecasts useful and established nationwide forecasts in 1927. These forecasts represent business firms' estimates of the goods they planned to ship and are thus a proxy for the demand for their goods. Figure 1 shows the actual and survey forecast of shippers' carloadings from 1927.2 to $1940.4 .^{5}$ Although our study ends in 1940,

\footnotetext{
${ }^{5}$ A carload is defined (Moore, 1961, Vol. II, p. 41) as a shipment of not less than 10,000 pounds of one commodity from one consignor to one consignee for Class I railroads, which had annual revenue exceeding $\$ 1$
} 
the surveys continued through the 1940s. However, government intervention and controls on railroads during World War II changed the essential character of the forecasts.

Figure 1

Actual and Survey Forecasts of Shippers' Carloadings

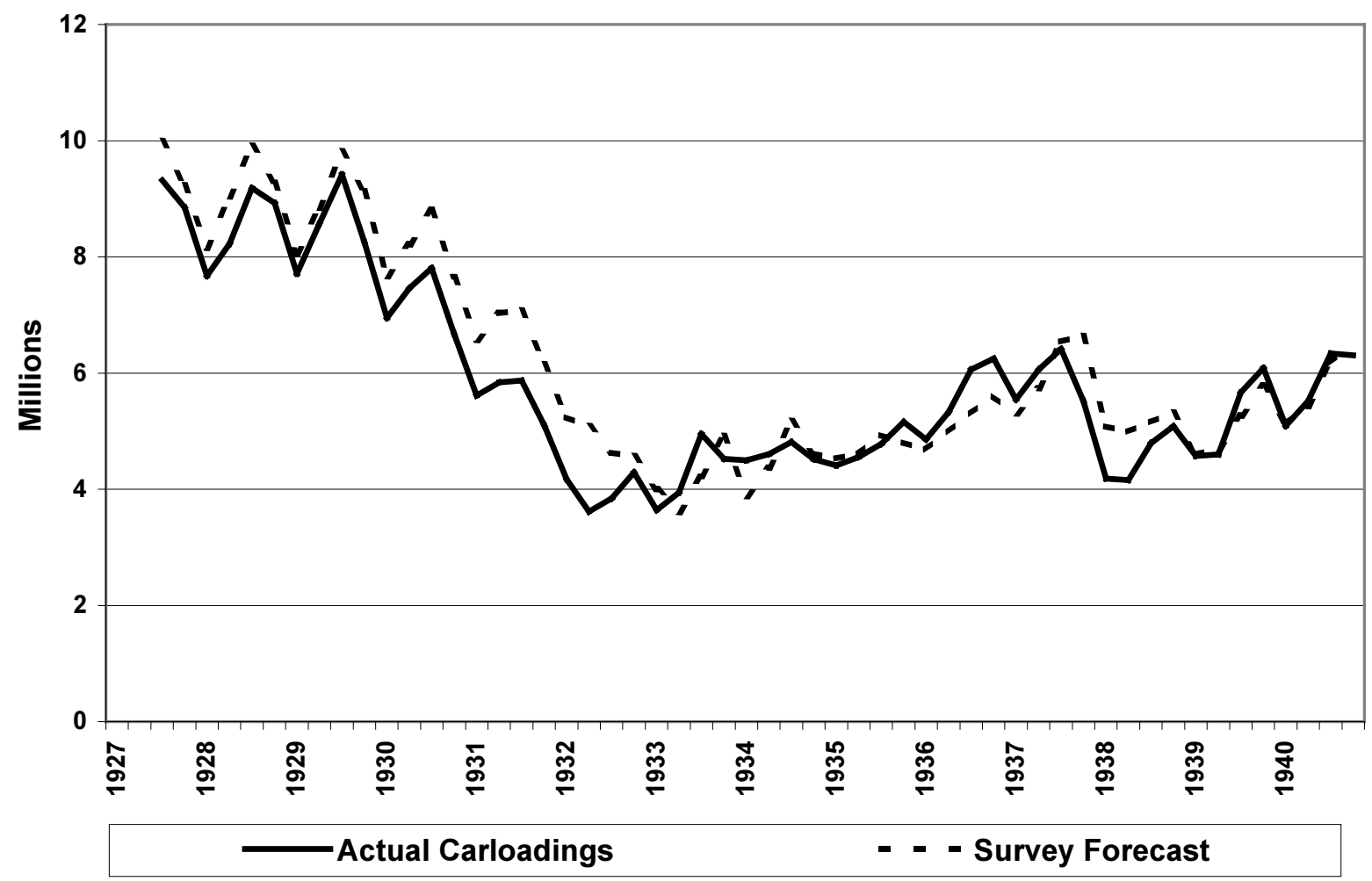

The forecast errors made by the shippers, shown in Figure 2, are measured as the difference between the actual and forecast carloadings as a fraction of actual carloadings. This graph tells a striking story about business expectations. Although the errors ranged from 3 to 10 percent in the three years before the Great Depression, this broad sample of businessmen made consistently larger errors after the crash of the stock market in October 1929. In the early years of the depression, they constantly overestimated the demand for freight cars. Their errors rose from 10 percent to nearly 30 percent by the third quarter of no adjustment for the increase in the size of freight cars, which grew by 29 percent between 1916 and 1951. 
1932. They appear to have been excessively optimistic, hoping that the economy would revive, but they were repeatedly surprised and made larger errors as the economy sank. In the second quarter of 1930, when Fisher termed the downturn "mild," shippers forecast they would require 8.2 million cars (8.6 million were needed in the second quarter of 1929) but only 7.5 million were used. Their worst failure occurred in the second quarter of 1932, when after projecting a demand for 5.1 million cars, 3.6 million were actually employed.

Figure 2

Shippers' Forecast Error

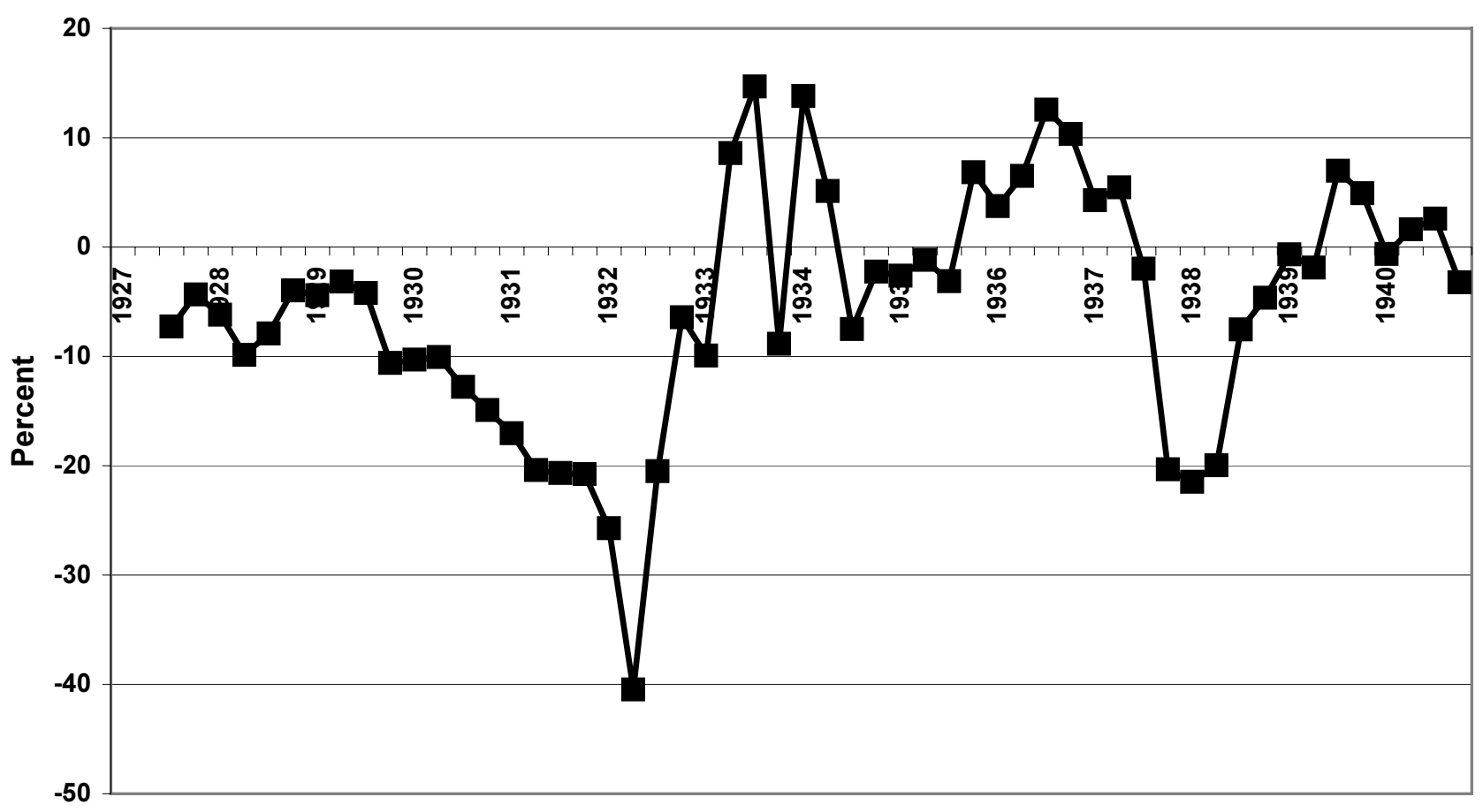

The survey errors also appear to show the surprise of the New Deal. According to Temin and Wigmore (1990), Roosevelt made a sharp unanticipated break with Hoover's policies once he was inaugurated in March 1933. Within six weeks of taking office, he devalued the dollar, promoted fiscal expansion and championed the virtues of reflation, thus sending a message to all industries of a new policy regime. The data on carloadings support this interpretation of events, as business did not anticipate the positive shocks to the economy. But, unlike the 
downward movement of the economy, their errors were not persistent. They underestimated demand by as much as 15 percent in several quarters in 1933 and 1934. The surprisingly good fortunes of the economy in 1936 were followed by a failure to anticipate the decline in demand for goods in 1937-1938. All in all, the railroad shippers, with their eye on business, do not seem to have done a much better job at prediction than Irving Fisher or his peers at Harvard.

\section{Survey Data and the Business Cycle}

Might these errors be the results of problems with the survey? Although this is a possibility, this survey data is largely immune from the criticism of some types of survey data. Contemporary macroeconomic surveys, like the Livingstone survey, ask professional economists and analysts for their forecasts. Keane and Runkle (1990) argue that these surveys are reliable guides to expectations because the individuals surveyed depend on their reputation as forecasters for their livelihood. On the other hand, others argue that forecasters answers are affected by strategic motives for introducing systematic bias into publicly available forecasts (Ehrbeck and Waldmann, 1986). While not completely safe from these criticisms, traffic managers' livelihoods did depend on producing accurate reports. There may have been some strategic behavior; but in most industries, each firm was sufficiently small that it could not hope to influence the outcome. Furthermore, one contemporary expert (Hultgren, 1948) saw no change in the movement of empty cars from 1920 onwards that might have been an indication of strategic behavior after the introduction of the survey. Another possible source of bias would be shippers loss functions; if these were asymmetric, it could create the appearance of bias. 
The data collected in this survey are not the longest nor the most comprehensive time series. As surveying was costly, the AAR included only the "more important kinds of carload traffic" (Hultgren, 1955, p. 363). In 1949, for example, the actual carloadings of the commodities included in the forecasts were 91 percent of the number of carloadings reported to the Interstate Commerce Commission and 76 percent of all known carloadings. Additional data on freight carloadings was collected by the AAR beginning in 1918. These data are fairly comprehensive for rail traffic, but they do not represent the actual total carloadings for any month or quarter. The reported numbers are derived from weekly averages, which may not correspond exactly to the reported month. Figure 3 displays the two series for actual freight carloadings. The actual carloadings that were included in the reports of the shippers' forecasts are lower because only major commodities were included. Nevertheless, the two series are very closely correlated for the period 1927.2 to 1940.4 , when they overlap, with a correlation coefficient of 0.994 .

Carloadings have some limitations as measures of economic activity and freight-ton miles would be a better indication of the services rendered by the railroads. However, carloadings are a good proxy for general economic activity even though agricultural commodities bulked larger in carloadings than in an index of industrial production. Table 1 shows the actual and estimated carloadings by commodity for the first quarter of 1930 . The shares of each group in the total of actual and estimated carloadings are also reported. For comparison, the Federal Reserve Board Index of Industrial Production with 1927 weights is presented in the table, along with the weights for each group. Approximately, 21 percent of the industrial production index is not found in the data on carloadings and the weights on the represented groups differ significantly. To determine how well carloadings can be used as a 
measure of industrial activity, the carloadings were weighted by the Federal Reserve Board weights, with zero weights attached to the excluded groups.

Figure 3

Actual AAR and Shippers' Carloadings

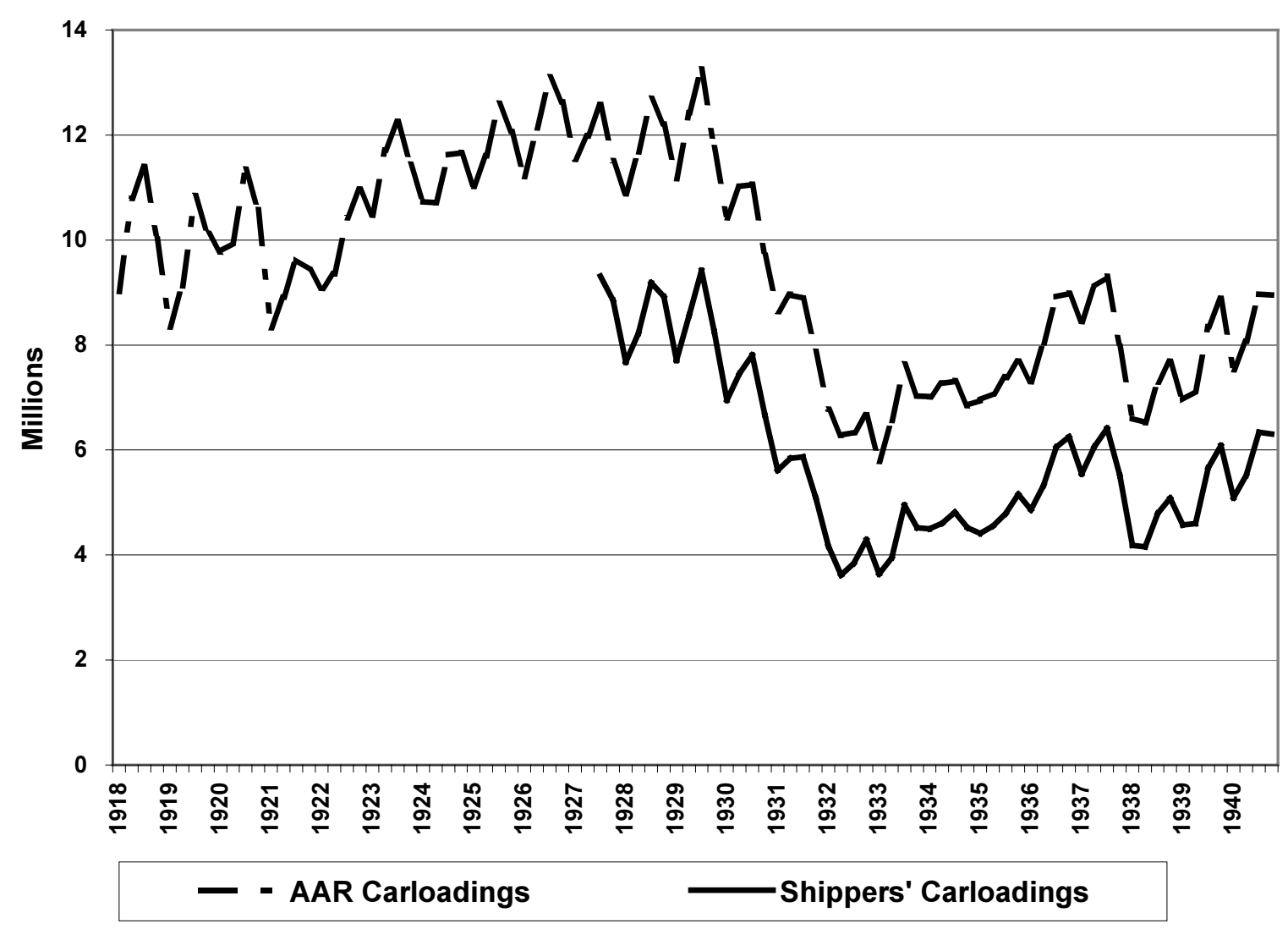


Table 1

Composition of the AAR Carloadings and the FRB Index of Industrial Production

1 Grain, All

2 Flour, meal and Other Mills Products

3 Hay, Straw and Alfalfa

4 Cotton

5 Cotton Seed and Product Except Oil

6 Citrus Fruits

7 Other Fresh Fruits

8 Potatoes

9 Other Fresh Vegetables

10 Livestock

11 Poultry and Diary Products

12 Coal and Coke

13 Ore and Concentrates

14 Gravel, Sand and Stone

15 Salt

16 Lumber and Forest Products

17 Petroleum and Petrleum Products

18 Sugar, Syrup and Molasses

19 Iron and Steel

20 Machinery and Boilers

21 Cement

22 Brick and Clay Products

23 Lime and Plaster

24 Agricultural Implements and Other Vehicles

25 Automobiles, Trucks and Parts

26 Fertilizers, All Kinds

27 Paper, Paperboard and Prepared Roofing

28 Chemicals and Explosives

29 Canned Goods-All Canned Food Products

\begin{tabular}{|c|c|c|c|c|c|}
\hline Actual & Estimated & $\begin{array}{c}\text { Actual } \\
\text { Carloadings }\end{array}$ & $\begin{array}{l}\text { Estimated } \\
\text { Carloadings }\end{array}$ & $\begin{array}{c}\text { Group } \\
\text { Share of }\end{array}$ & \\
\hline Carloadings $\mathrm{C}$ & Carloadings & Percent & Percent & 1927 & \\
\hline 1930.1 & 1930.1 & of Total & of Total & FRB Index & x FRB Industrial Production Group \\
\hline 296,233 & 302,316 & 5.57 & 4.82 & & \\
\hline 227,669 & 242,076 & 4.28 & 3.86 & 2.1 & Flour-mills Products \\
\hline 54,703 & 76,722 & 1.03 & 1.22 & & \\
\hline 40,367 & 48,000 & 0.76 & 0.77 & 9.1 & Cotton Goods \\
\hline 36,884 & 51,270 & 0.69 & 0.82 & & \\
\hline 51,632 & 50,312 & 0.97 & 0.80 & & \\
\hline 48,275 & 46,085 & 0.91 & 0.74 & & \\
\hline 67,863 & 62,380 & 1.28 & 1.00 & & \\
\hline 71,097 & 68,572 & 1.34 & 1.09 & & \\
\hline 280,260 & 295,691 & 5.27 & 4.72 & 5.5 & Slaughtering and Meat Packing \\
\hline 38,081 & 32,811 & 0.72 & 0.52 & & \\
\hline $2,088,414$ & $2,379,632$ & 39.29 & 37.98 & 7.1 & Coke and Coal \\
\hline 76,866 & 103,021 & 1.45 & 1.64 & 2.0 & Iron Ore and Other Metal Shipments \\
\hline 250,934 & 342,065 & 4.72 & 5.46 & & \\
\hline 28,481 & 28,399 & 0.54 & 0.45 & & \\
\hline 477,960 & 664,774 & 8.99 & 10.61 & 8.8 & Lumber and Allied Products \\
\hline 508,409 & 551,055 & 9.56 & 8.79 & 5.3 & Petroleum Refining \\
\hline 37,759 & 42,013 & 0.71 & 0.67 & 1.3 & Sugar Refining \\
\hline 312,745 & 403,739 & 5.88 & 6.44 & 20.5 & Iron and Steel and their Products \\
\hline 31,245 & 39,714 & 0.59 & 0.63 & & \\
\hline 78,267 & 88,678 & 1.47 & 1.42 & 1.2 & Cement Production \\
\hline 70,990 & 99,038 & 1.34 & 1.58 & 1.3 & Clay Products \\
\hline 32,110 & 39,967 & 0.60 & 0.64 & & \\
\hline 21,531 & 30,583 & 0.41 & 0.49 & & \\
\hline 125,619 & 160,805 & 2.36 & 2.57 & 5.3 & Motor Vehicles, Including Bodies and Parts \\
\hline 111,554 & 153,967 & 2.10 & 2.46 & & \\
\hline 78,283 & 90,220 & 1.47 & 1.44 & 10.0 & Paper and Printing \\
\hline 22,115 & 27,700 & 0.42 & 0.44 & & \\
\hline \multirow[t]{8}{*}{45,815} & 46,851 & 0.86 & 0.75 & & \\
\hline & & & & 3.6 & Leather and its Manufactures \\
\hline & & & & 1.6 & Rubber Products \\
\hline & & & & 1.0 & Tobacco Manufactures \\
\hline & & & & 9.2 & Woolen, Worsed and Silk Goods \\
\hline & & & & 1.2 & Glass \\
\hline & & & & 3.6 & Other Metal and Metal Products \\
\hline & & & & 0.6 & Locomotives, Ship and Boat Building \\
\hline $5,315,928$ & $6,266,140$ & 100.0 & 100.0 & 100.0 & \\
\hline
\end{tabular}

Total

Source: National Forecast of the Regional Shippers' Advisory Boards (1930,1931), Federal Reserve Bulletin (February 1927), 102-3. 
Figure 4 charts the Federal Reserve Board's index of industrial production and the FRB weighted-carloadings. The weighted carloadings track industrial production fairly closely until 1934. These series recover from the nadir of the depression in 1933; but carloadings, unlike industrial production, never returns to its pre-1930 levels. This break in the series produces a low correlation of 0.56 between them for the whole period. ${ }^{6}$ However, breaking the period at the end of 1933, yields a correlation coefficient of 0.92 for 1927.21933.4 and 0.87 for 1934.1-1940.4. Thus, except for the break, fluctuations in carloadings generally follow industrial activity.

Figure 4

Indexes of Economic Activity

$1927.2=100$

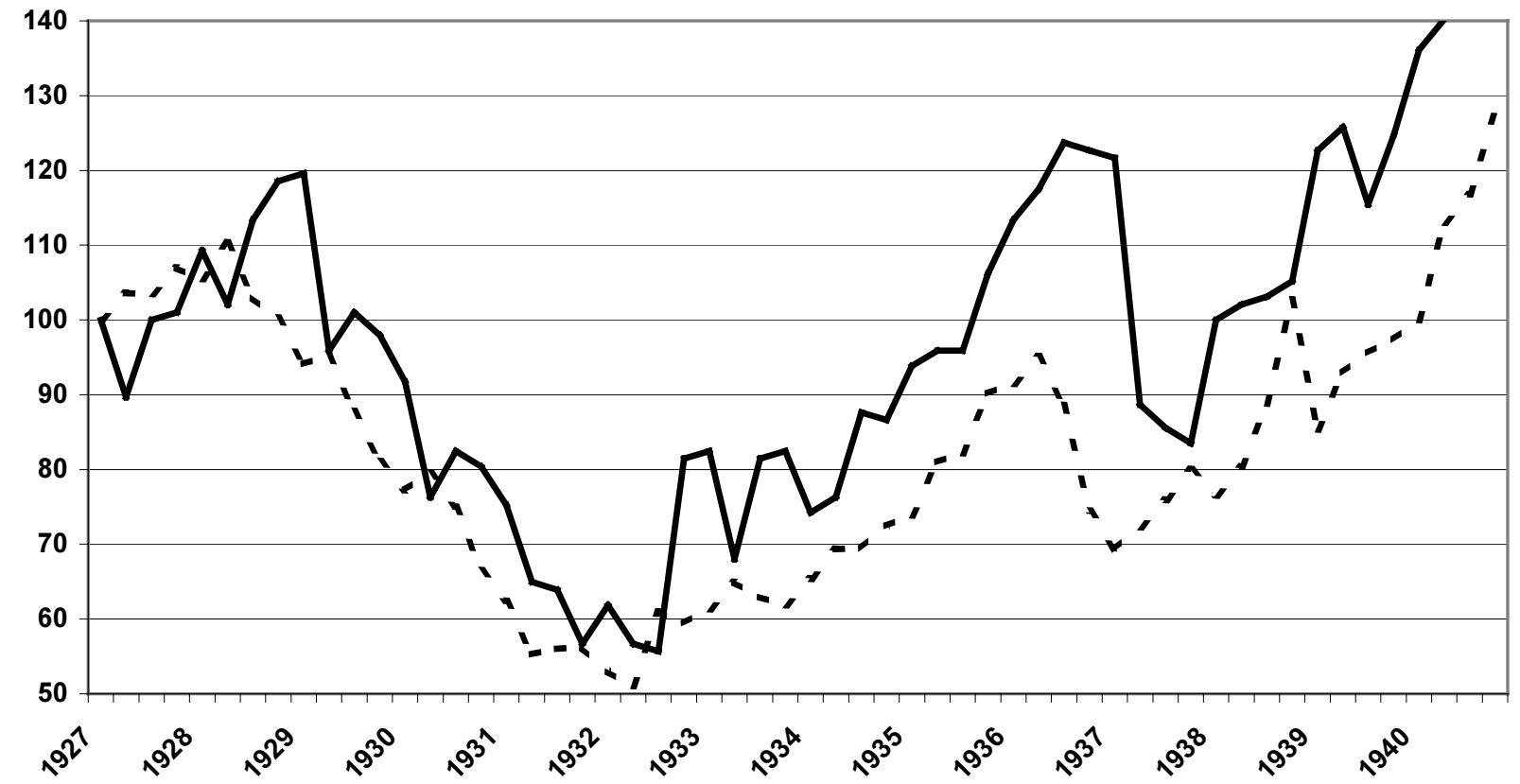

FRB Industrial Production - - - Weighted Carloadings

\footnotetext{
${ }^{6}$ The correlation coefficient between actual carloadings and industrial production is 0.475 for the whole period.
} 
The reason for this shift in the level of carloadings is the loss of traffic to trucks and pipelines. In 1930, railroads hauled 74.3 percent of the 524 billion freight ton-miles, with trucks accounting for 3.9 and pipelines 5.3 percent. By 1940, total freight-ton miles reached 618 billion freight-ton miles, but railroads had only 61.3 percent, while trucks and pipelines picked up 10.0 and 9.6 percent respectively (Stover, 1961). One reason for this shift was that rail freight rates declined very little during the contraction of 1929-1933. The Interstate Commerce Act (1887), as amended by the Transportation Act (1920) had given the Interstate Commerce Commission the power to establish maximum and minimum rates among other broad powers of regulation. When railroad revenues fell in the early 1930s, the industry appealed for a 15 percent increase in freight rates in 1931. This plea was not answered and rates were slightly increased an average of 2.6 percent. Yet, raising prices while other prices tumbled is astonishing. In contrast, trucking was a highly competitive industry. Truck transport, unlike rail transport was easy to enter, with the government providing the highways. Trucks could be bought second hand and wages were determined by the market not the railroad union or federal legislation. The loss of business to trucking helped to secure the passage of the Motor Carrier Act in 1935, which regulated truck rates, but it had relatively little effect in the period under consideration (Hultgren, 1948; O'Brien, 1989).

\section{Better Forecasts?}

The survey of shippers covered hundreds of firms and should have given a reasonable measurement of business expectations. The large and repeated errors of the early 1930s are quite surprising and raise the question whether business could have done a better job of forecasting the depression. These forecasts of transportation services, which seem to proxy 
industrial production, fail in a fashion analogous to the forecasts of future prices of commodities found by Hamilton (1987). Cecchetti (1992) raised the question of whether deflation and ex ante real rates of interest could have been predicted with accuracy, estimating ARMA models of inflation and examining the properties of the forecasts from these models. In this section, we examine whether a simple ARMA model or rule of thumb using carloading data could have outperformed the railroad shippers.

A key problem is that the actual data on shippers' carloadings corresponding to the shippers' forecasts is only available as far back as the third quarter of 1927, creating a paucity of data on which to forecast the events of the early 1930s. To fill in the gap, we use the more comprehensive AAR carloading series, shown in Figure 2, to reconstruct the shippers' carloadings back to the first quarter of 1918 . The very closely correlated movement of the two series led us to construct a new series, ActualShipCL for 1918.1 to 1927.2 by the following formula:

$$
\text { ActualShipCL }_{\mathrm{t}-1}=\text { ActualShipCL }_{\mathrm{t}}\left(1+\frac{\left(\text { AARCarloadings }_{\mathrm{t}-1}-\text { AARCarloadings }_{\mathrm{t}}\right)}{\text { AARCarloadings }_{\mathrm{t}}}\right) .
$$

That is, the percentage change in the AAR Carloadings series from period t to period t- 1 was used to extend the ActualShipCL series back to the start of the sample. Figure 5 contains a graph of the extended series together with the AAR Carloadings series. Our forecasting analysis uses the ActualShipCL series. 
Figure 5

AAR Carloadings and Extended Shippers' Carloadings

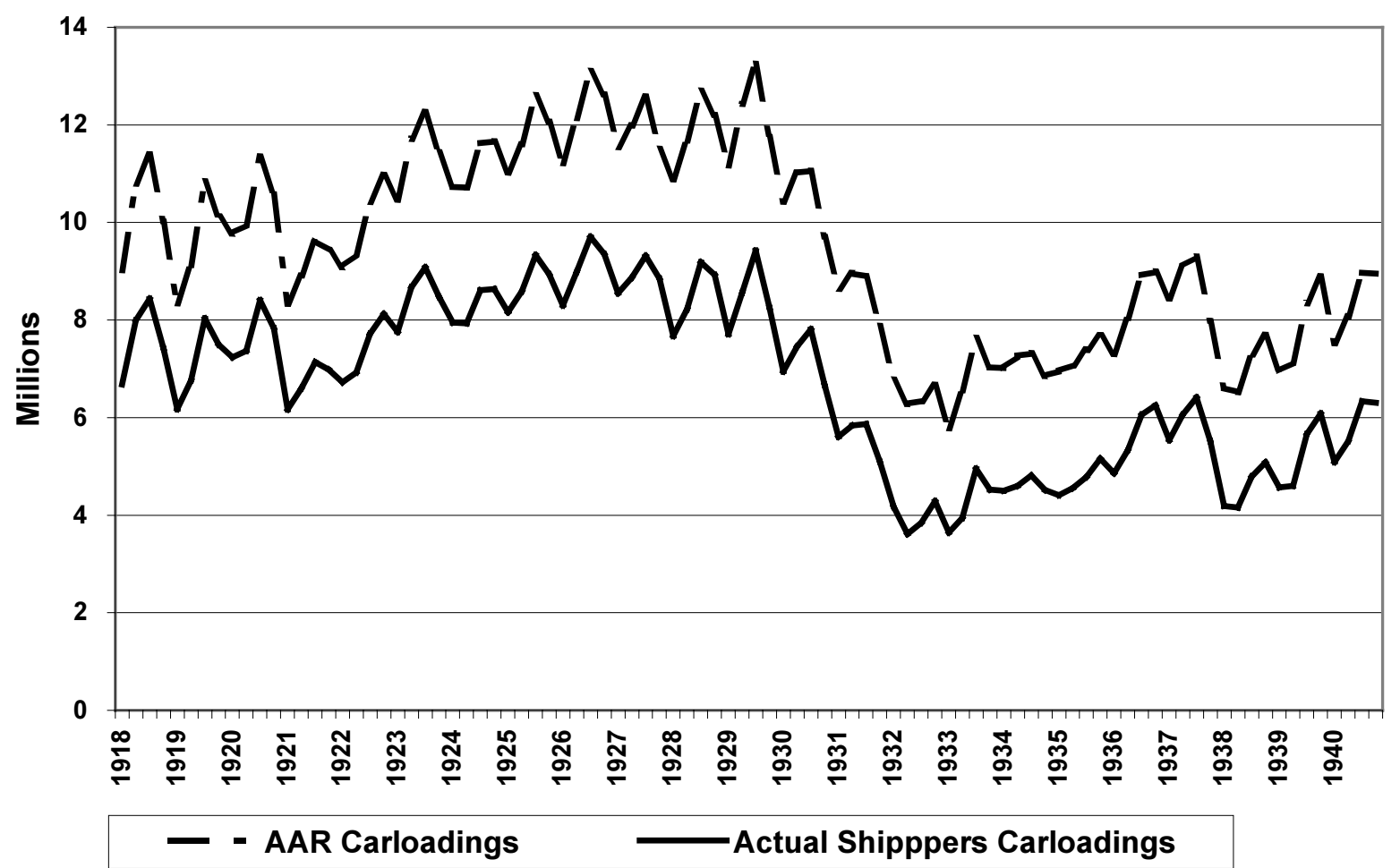

Could a time series econometrician have forecasted the downturn of the early 1930s better than the shippers in the survey? To answer this question, we used an ARIMA time series forecasting model, using the Box-Jenkins modeling philosophy. To select the appropriate ARIMA model, we needed to identify any non-stationary components in the data. Given the strong seasonal nature of the data, the seasonal unit test of Hylleberg et. al. (1990) was used.; the results are reported in Table 2. There was evidence of a unit root in the data at the long run frequency and the quarterly frequency but not at the half-yearly frequency. Hence the data needed to be $1^{\text {st }}$ differenced and $4^{\text {th }}$ differenced to make it stationary. This data on carloadings thus shares characteristics of many macroeconomic time series. 
Table 2

Seasonal Integration Tests

\begin{tabular}{|c|c|c|c|}
\hline Null Hypothesis & Critical Value $^{7}$ & Rejection Region & Test Statistic \\
\hline $\mathrm{I}_{0}(1)$ & -2.88 & $<-2.88$ & -1.5009 \\
\hline $\mathrm{I}_{1 / 2}(1)$ & -1.95 & $<-1.95$ & -2.865 \\
\hline $\mathrm{I}_{1 / 4}(1)$ & 3.08 & $>3.08$ & 1.08 \\
\hline
\end{tabular}

Letting $y_{t}=$ ActualShipCL $_{\mathrm{t}}$, we sought to fit the best $\operatorname{ARMA}(\mathrm{p}, \mathrm{q})(\mathrm{P}, \mathrm{Q})_{4}{ }^{8}$ model to the stationary time series, $y_{t}{ }^{*}$, where

$$
y_{t}^{*}=(1-L)\left(1-L^{4}\right) y_{t} \text {. }
$$

The model that minimizes both the Akaike's Information Criterion (AIC) and the Schwarz Bayesian Information Criterion (SBIC) was the $\operatorname{ARIMA}(3,1,3)(0,1,1)_{4}$ model. This model was estimated using data for the period 1918:1 until 1927:2 and 1-step ahead out of sample forecasts were produced using this model. Figure 6 graphs the forecast errors from ARIMA model and the survey forecast errors for 1927:3 to 1940:4.

Obviously, the men in the back offices of the railroads in the 1930s would not have had today's best practice time series forecasting technology. However, they were familiar with patterns of seasonality and plotted trends. As a possible approximation to some simple rules they might have used, we tried the Holt-Winters ${ }^{9}$ exponential smoothing forecasting model, which allows for a changing level, trend and seasonality:

$$
y_{t}^{f}=\left(a_{t-1}+b_{t-1}\right) c_{t-4}
$$

\footnotetext{
${ }^{7}$ Critical values for sample size 100 with an included constant in the regression equation. Source: Patterson(2000)

${ }^{8}$ Note that $\mathrm{p}$ and $\mathrm{q}$ refer to the AR and MA order while $\mathrm{P}$ and $\mathrm{Q}$ refer to the Seasonal AR and MA orders.

${ }^{9}$ For a reference to this forecasting method see Granger and Newbold (1977), Pindyck and Rubinfeld (1991), Makridakis, Wheelright, and Hyndman (1998). This method is very much in the spirit of Ferber's study (1953) of railroad shippers forecasts. Lovell (1964) also compared a simple model of regressive expectations with the survey forecasts for the period 1947-1956.
} 
Figure 6

Survey and ARIMA Forecast Errors

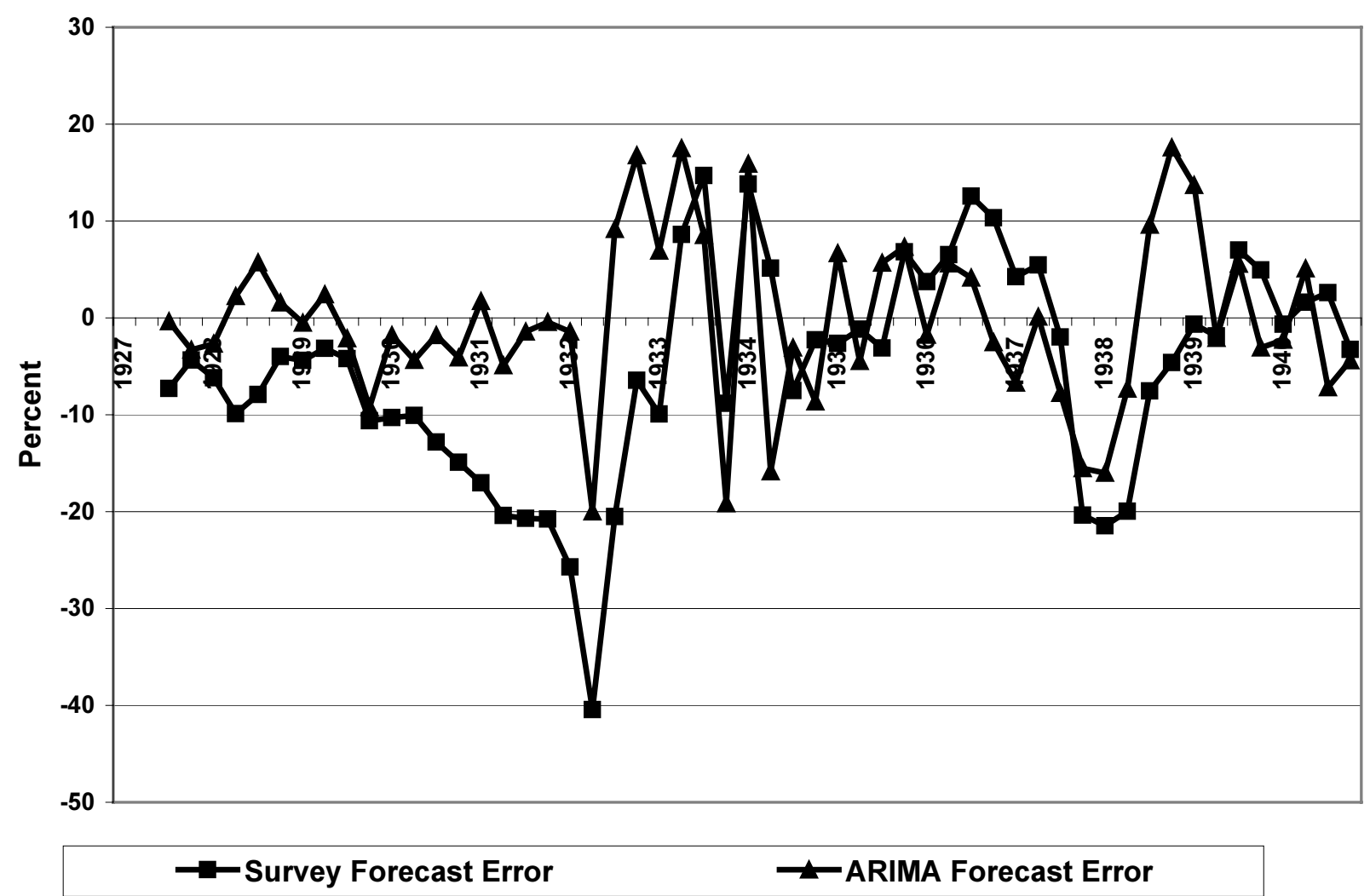

where

$$
\begin{aligned}
& a_{t}=\alpha \frac{y_{t}}{c_{t-4}}+(1-\alpha)\left(a_{t-1}+b_{t-1}\right) \\
& b_{t}=\beta\left(a_{t}-a_{t-1}\right)+(1-\beta) b_{t-1}
\end{aligned}
$$

and

$c_{t}=\gamma \frac{y_{t}}{a_{t}}+(1-\gamma) c_{t-4}$

Here, $a_{t}$ represents the local mean of the data, $b_{t}$ represents the local trend and $c_{t}$ is the seasonal factor. Values for $\alpha, \beta$, and $\gamma$ gamma were chosen to minimize out of sample forecast errors for the period 1920:1 to 1927:2. The values chosen were $0.99,0.2$ and 0.2 respectively. These values were then used to calculate one-step ahead forecasts for the period 1927:3 to 
1940:4. The errors for the Winters method and the survey forecast errors are depicted in Figure 7.

Figure 7

Holts-Winters and Survey Forecast Errors

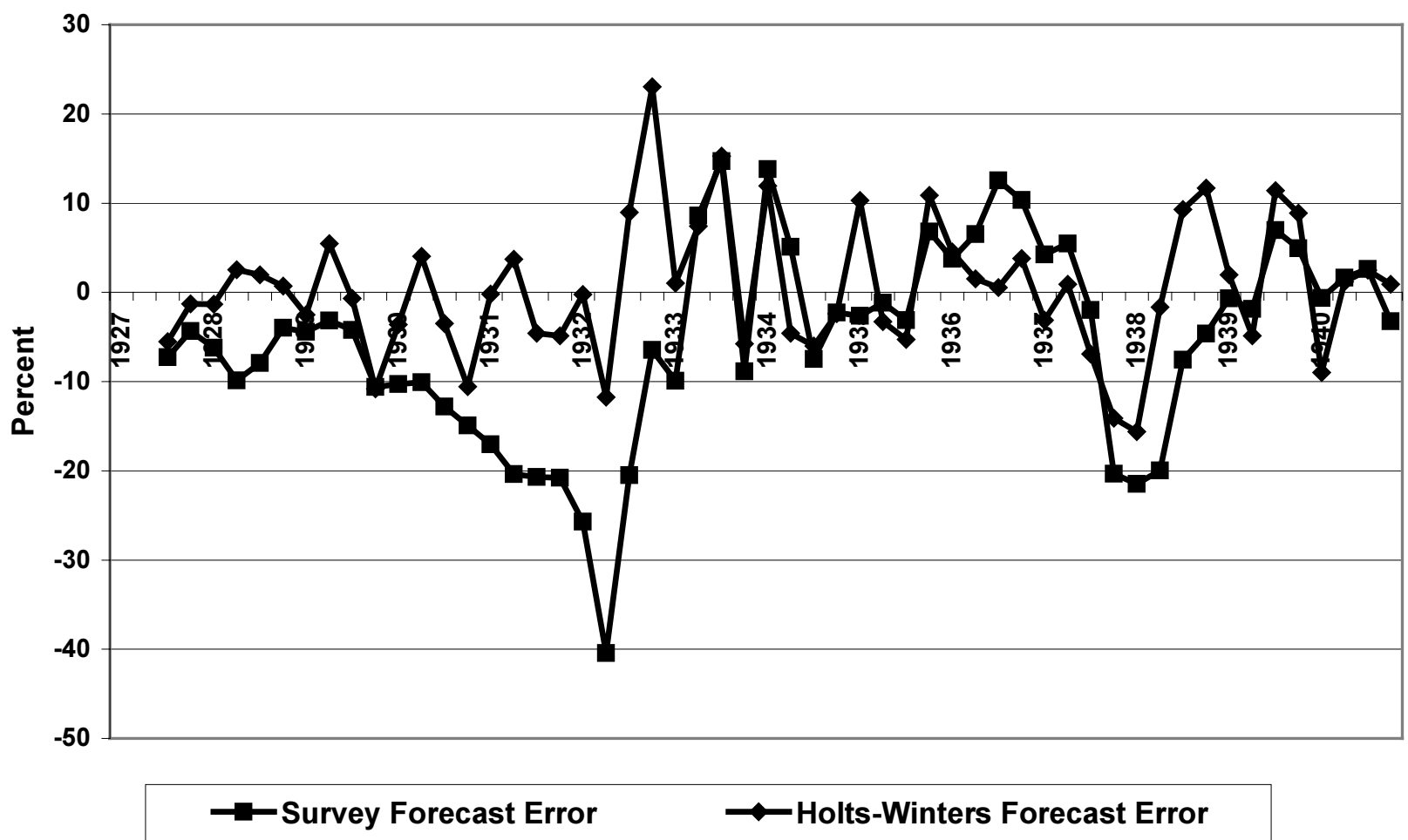

The forecast diagnostics for all three forecasting efforts are shown in Table 3, which contains the root mean squared forecast error (RMSE), Theil's U statistic, and a decomposition of the RMSE into its bias, variance and covariance components. The bias component represents the proportion of the RMSE that is attributable to bias in the forecast, while the variance component represents the proportion of the RMSE that can be explained by getting the variance of the forecast wrong. The covariance component represents the unexplained portion of the RMSE. 
Table 3

Forecast Diagnostics

\begin{tabular}{|c|c|c|c|c|c|}
\hline $\begin{array}{c}\text { Forecast } \\
\text { Method }\end{array}$ & RMSE & Theil's U & Bias & Variance & Covariance \\
\hline Winters & 392,339 & 0.032 & 0.0005 & 0.0729 & 0.9265 \\
\hline ARIMA & 417,469 & 0.034 & 0.0051 & 0.0539 & 0.9410 \\
\hline Survey & 631,402 & 0.051 & 0.2355 & 0.0782 & 0.6863 \\
\hline
\end{tabular}

Figures 6 and 7 and Table 3 provide disturbing evidence on the accuracy of contemporary business forecasts. As Theil's U for all forecasts is considerably less than one, all methods forecast carloadings better than a naïve forecast using the previous observation. However, as is evident in the size of the RMSE, business' performance was notably worse. Forecasts by the ARIMA or the Holt-Winters model reduced the error by about one-third, approximately 200,000 railroad cars a quarter. The source of most of this higher error---the mistakes during the Great Depression---is evident in Figures 6 and 7. Both forecasting methods avoid the growing error of the shippers because the constant bad news feeds into a mechanical lowering of future forecasts. The large error in the survey forecast shows up in the large bias in Table 3. While the shippers did not estimate the variance of the fluctuations as well as an ARIMA model could have, they did not do worse than the Holt-Winters model. Interestingly, business' forecasts of recovery and the effects of the New Deal are better. Even though large errors were made, business clearly absorbed additional information beyond the past history of carloadings. The sharp downturn of 1937-1938 took the railroads by surprise, and neither forecasting model is better in predicting this recession.

The failure of business to anticipate 1930-1933 stands out. Business could have projected their demand for freight cars with greater accuracy---they appear not to have been able to believe what was happening to the economy. The results parallel the findings of Hamilton and Cecchetti. In his analysis of price forecasts embodied in futures prices, 
Hamilton found that investors in the market consistently and cumulatively erred, failing to anticipate the prolonged price decline of the early 1930s. The survey data on the expected demand for freight carloadings shows similar consistent and continuing errors at the same time horizons, indicating that producers, like investors, Irving Fisher and other contemporary forecasters, did not believe that the economic slide would continue. Yet, had the public projected price movements, as Cecchetti suggests they could have done, their errors would have been considerably smaller. Likewise, traffic managers could have used forecasts based on the past record of carloadings with much greater success. Fortunately, we can examine the sources of traffic managers errors more closely as they provided forecasts by commodity. ${ }^{10}$

\section{The Composition of the Forecasts}

The railroad shippers's reports provide detailed forecasts for twenty-nine goods. Tables 4 and 5 provide forecast diagnostics for the survey forecasts and the forecast using the Holt-Winters procedure. As we were unable to extend the series back before 1928, we did not attempt to use an ARIMA model to produce out-of-sample forecasts, as the depression was immediately on the horizon. However, as the results above demonstrate, the Holt-Winters forecasts are not inferior to our ARIMA model for the aggregate carloadings.

\footnotetext{
${ }^{10}$ We do not examine the question of whether the forecasts were rational, as the bias in the estimates, is often difficult to interpret. See Webb (1987), Keane and Runkle (1990), and Bonham and Carter (1995).
} 
Table 4

Survey Forecast Diagnostics by Commodity

\begin{tabular}{|c|c|c|c|c|c|}
\hline Commodity & RMSE & Theils U & Bias Proportion & Variance Proportion & Covariance Proportion \\
\hline Grain ,All & 38,024 & 0.0641 & 0.0651 & 0.0400 & 0.8948 \\
\hline Flour, Meal \& Other Mill Products & 16,867 & 0.0413 & 0.1822 & 0.0319 & 0.7859 \\
\hline Hay, Straw and Alfalfa & 11,218 & 0.1227 & 0.0189 & 0.0159 & 0.9652 \\
\hline Cotton & 15,713 & 0.1066 & 0.1135 & 0.1299 & 0.7566 \\
\hline Cotton Seed \& Products, Except Oil & 11,151 & 0.1436 & 0.0305 & 0.0580 & 0.9115 \\
\hline Citrus Fruits & 6,088 & 0.0928 & 0.0003 & 0.0060 & 0.9937 \\
\hline Other Fresh Fruits & 12,251 & 0.0744 & 0.1792 & 0.0567 & 0.7641 \\
\hline Potatoes & 8,864 & 0.0776 & 0.0088 & 0.0156 & 0.9756 \\
\hline Other Fresh Vegetables & 7,209 & 0.0563 & 0.0017 & 0.0084 & 0.9899 \\
\hline Live Stock & 33,669 & 0.0662 & 0.0905 & 0.0079 & 0.9017 \\
\hline Poultry and Dairy Products & 3,394 & 0.0519 & 0.0001 & 0.0037 & 0.9962 \\
\hline Coal and Coke & 226,311 & 0.0571 & 0.2819 & 0.1124 & 0.6057 \\
\hline Ore and Concentrates & 94,750 & 0.1130 & 0.0001 & 0.0247 & 0.9752 \\
\hline Clay, Gravel, Sand and Stone & 79,771 & 0.0833 & 0.2294 & 0.3098 & 0.4608 \\
\hline Salt & 5,220 & 0.0956 & 0.0208 & 0.0370 & 0.9422 \\
\hline Lumber and Forest Products & 86,498 & 0.0793 & 0.1822 & 0.0453 & 0.7725 \\
\hline Petroleum and petroleum Products & 41,777 & 0.0404 & 0.1242 & 0.0083 & 0.8675 \\
\hline Suger, Syrup, Glucose \& Molasses & 7,051 & 0.0784 & 0.0220 & 0.0002 & 0.9778 \\
\hline Iron and Steel & 72,940 & 0.1001 & 0.0109 & 0.0161 & 0.9730 \\
\hline Castings, Machinery \& Boilers & 6,113 & 0.0860 & 0.0890 & 0.0302 & 0.8808 \\
\hline Cement & 19,074 & 0.0660 & 0.1290 & 0.1211 & 0.7499 \\
\hline Brick and Clay Products & 17,031 & 0.0932 & 0.2347 & 0.1408 & 0.6245 \\
\hline Lime and Plaster & 5,602 & 0.0712 & 0.1447 & 0.0593 & 0.7960 \\
\hline Agric. Implements \& Vehicles & 4,655 & 0.1098 & 0.0529 & 0.0572 & 0.8899 \\
\hline Automobiles, Trucks and Parts & 30,509 & 0.0917 & 0.1854 & 0.0118 & 0.8028 \\
\hline Fertilizers, All Kinds & 14,265 & 0.0823 & 0.0005 & 0.0021 & 0.9974 \\
\hline Paper, Printed Matter and Books & 10,642 & 0.0624 & 0.0058 & 0.0000 & 0.9942 \\
\hline Chemicals and Explosives & 10,826 & 0.1958 & 0.0768 & 0.3200 & 0.6031 \\
\hline Canned Goods & 7,486 & 0.0833 & 0.0001 & 0.0002 & 0.9997 \\
\hline Total All Commodities Listed & 521,760 & 0.0419 & 0.0168 & 0.0038 & 0.9793 \\
\hline
\end{tabular}


Table 5

Holt-Winters Forecast Diagnostics by Commodity

\begin{tabular}{|c|c|c|c|c|c|}
\hline Commodity & RMSE & Theils U & $\begin{array}{c}\text { Bias } \\
\text { Proportion }\end{array}$ & $\begin{array}{l}\text { Variance } \\
\text { Proportion }\end{array}$ & Covariance Proportion \\
\hline Grain ,All & 51,196 & 0.0891 & 0.0001 & 0.0001 & 0.9998 \\
\hline Flour, Meal \& Other Mill Products & 12,237 & 0.0306 & 0.0001 & 0.0157 & 0.9842 \\
\hline Hay, Straw and Alfalfa & 7,850 & 0.0890 & 0.0000 & 0.0455 & 0.9545 \\
\hline Cotton & 17,698 & 0.1262 & 0.0000 & 0.0001 & 0.9999 \\
\hline \multicolumn{6}{|l|}{ Cotton Seed \& Products, Except } \\
\hline Oil & 11,783 & 0.1657 & 0.0063 & 0.1101 & 0.8836 \\
\hline Citrus Fruits & 6,888 & 0.1041 & 0.0009 & 0.0451 & 0.9540 \\
\hline Other Fresh Fruits & 13,127 & 0.0824 & 0.0004 & 0.0066 & 0.9931 \\
\hline Potatoes & 9,692 & 0.0856 & 0.0002 & 0.0575 & 0.9423 \\
\hline Other Fresh Vegetables & 10,649 & 0.0832 & 0.0000 & 0.0048 & 0.9952 \\
\hline Live Stock & 38,062 & 0.0774 & 0.0002 & 0.0204 & 0.9795 \\
\hline Poultry and Dairy Products & 3,207 & 0.0491 & 0.0010 & 0.0176 & 0.9814 \\
\hline Coal and Coke & 180,225 & 0.0475 & 0.0001 & 0.0691 & 0.9309 \\
\hline Ore and Concentrates & 130,842 & 0.1488 & 0.0008 & 0.1138 & 0.8854 \\
\hline Clay, Gravel, Sand and Stone & 51,828 & 0.0577 & 0.0070 & 0.0002 & 0.9928 \\
\hline Salt & 1,964 & 0.0356 & 0.0020 & 0.0084 & 0.9896 \\
\hline Lumber and Forest Products & 50,948 & 0.0493 & 0.0036 & 0.0718 & 0.9246 \\
\hline Petroleum and petroleum Products & 26,996 & 0.0265 & 0.0005 & 0.0264 & 0.9731 \\
\hline Suger, Syrup, Glucose \& Molasses & 5,845 & 0.0664 & 0.0004 & 0.0102 & 0.9893 \\
\hline Iron and Steel & 57,771 & 0.0800 & 0.0036 & 0.0322 & 0.9642 \\
\hline Castings, Machinery \& Boilers & 4,459 & 0.0651 & 0.0034 & 0.0321 & 0.9645 \\
\hline Cement & 13,546 & 0.0483 & 0.0039 & 0.0059 & 0.9902 \\
\hline Brick and Clay Products & 9,829 & 0.0577 & 0.0044 & 0.0224 & 0.9733 \\
\hline Lime and Plaster & 3,781 & 0.0501 & 0.0051 & 0.0122 & 0.9827 \\
\hline Agric. Implements \& Vehicles & 3,203 & 0.0790 & 0.0037 & 0.0120 & 0.9844 \\
\hline Automobiles, Trucks and Parts & 53,603 & 0.1685 & 0.0013 & 0.0321 & 0.9666 \\
\hline Fertilizers, All Kinds & 15,774 & 0.0946 & 0.0032 & 0.0037 & 0.9932 \\
\hline Paper, Printed Matter and Books & 6,571 & 0.0389 & 0.0008 & 0.0313 & 0.9679 \\
\hline Chemicals and Explosives & 2,401 & 0.0486 & 0.0034 & 0.0238 & 0.9728 \\
\hline Canned Goods & 8,376 & 0.0932 & 0.0003 & 0.0008 & 0.9989 \\
\hline Total All Commodities Listed & 404,692 & 0.0329 & 0.0039 & 0.0517 & 0.9444 \\
\hline
\end{tabular}


Once again, by Theil's U, both methods are better than a naïve forecast of last period's value. In Table 4, what is striking are the commodities where the proportion of error from bias is high, indicating that these were the ones primarily responsible for the poor aggregate forecast. The commodities with high bias (greater than 10 percent) were intermediate or capital goods for industry and construction: coal, coke, clay, gravel, sand, stone, lumber, petroleum, iron, steel, machinery, cement, bricks, lime, plaster, automobiles, and trucks. In contrast, the forecast of the demand for railroad cars for agricultural goods display much less bias. This difference disappears in the measure of bias in the estimates by the Holt-Winters procedure in Table 5. By this method, there is no visible difference between the errors made in forecasting carloadings for industrial goods and agricultural goods.

Prices for agricultural goods plunged during the depression, but consumption of foodstuffs and agricultural products was stable by comparison. The greatest challenge for the traffic managers was to predict whether there would be a bumper crop or crop failure, and hence there were some large random errors. However, there were no long streaks of large and growing errors in the forecasting for agricultural commodities. What the traffic managers did not expect was the decline in industrial products and construction materials. Demand for these products collapsed as the economy slid into the depression. Their prices certainly declined but not enough to avoid a decline in inventories and production.

\section{Deflation and Demand Surprises}

This study of expectations of the Great Depression offers new insight into the debate over whether the economic decline was anticipated. Although Hamilton $(1987,1992)$ and Cecchetti (1992) argue over whether the price decline was anticipated; this examination of 
railroad shippers forecasts helps to reconcile them. Like the investors and speculators in the commodities futures markets or the forecasters at Harvard and Yale, the traffic managers at the railroads continued to make large errors, anticipating a recovery. They could not believe the steady decline in output (like others who could not believe the decline in prices), although simple rules or a modern ARIMA model would have advised them to pay attention to the most recent events. They could not believe that a depression of this length and depth could happen; the economy surely had reached bottom and had to rebound.

The recessions in recent experience had been brief. The peak to trough was 18,14 and 13 months for the recessions of January 1920-July 1921 (of great severity), May 1923July 1924, and October 1926-November 1927. As seen in Figures 6 and 7, the survey forecasts track the 1929-1930 recession no worse than the two models into its fifth or sixth quarter. But, by the time the recession entered its second year, the large errors began to cumulate, suggesting that the railroads believed that a turnaround had to be imminent.

In Table 6, the percentage forecast errors made by railroad shippers are compared to the models and the forecasts provided by Cecchetti (1992) and Hamilton (1992). To construct a railroad shippers' forecast error similar to an inflation error, it is measured as the difference between the projected percentage increase in carloadings from the actual carloadings in the previous quarter less the actual percentage increase in carloadings. The forecast errors reported for Cecchetti's study are the differences between actual inflation, measured by the consumer price index, and expected inflation from a MA(2) model, an AR(1) model and an interest-rate model, while Hamilton's error is the difference between actual inflation and forecasts of inflation using commodity prices by trimester. Hamilton's errors from 1930.1 to 1933.1 are continuously negative reflecting a continued underestimation of deflation. This 
pattern is mirrored in the continued overestimation of demand by the railroad shippers for the duration of the economy's decline from 1929.3 to 1933.1. While not displaying this persistent mistake, all the other forecasts do show very large errors underestimating deflation and overestimating demand that swamp the errors in the other direction. This clear bias implies that even if businessmen and households had the best modern forecasting methods available they would still have been frequently surprised by deflation. Real expected interest rates were high, as Cecchetti and Romer have argued, but there was also considerable unanticipated deflation.

Table 6

Percentage Forecast Errors

\begin{tabular}{|c|c|c|c|c|c|c|c|c|}
\hline & $\begin{array}{l}\text { RR } \\
\text { Shippers }\end{array}$ & ARIMA & Holt-Winters & $\begin{array}{l}\text { Cecchetti } \\
\text { MA(2) }\end{array}$ & $\begin{array}{l}\text { Cecchetti } \\
A R(1)\end{array}$ & $\begin{array}{l}\text { Cecchetti } \\
\text { Interest }\end{array}$ & & Hamilton \\
\hline 1929.1 & -3.81 & -2.18 & -0.44 & -2.79 & -0.87 & -3.17 & 1929.1 & 0.54 \\
\hline 1929.2 & -3.51 & 6.09 & 2.68 & 7.10 & 2.89 & 5.00 & 1929.2 & 1.17 \\
\hline 1929.3 & -4.63 & -0.76 & -2.34 & 4.48 & 6.20 & 15.12 & 1929.3 & 4.35 \\
\hline 1929.4 & -9.31 & -9.47 & -8.09 & -10.19 & -7.33 & -3.26 & & \\
\hline 1930.1 & -8.66 & -3.06 & -1.51 & -4.46 & -5.54 & -1.97 & 1930.1 & -3.21 \\
\hline 1930.2 & -10.81 & 4.33 & -4.68 & 4.03 & 0.21 & -0.07 & 1930.2 & -3.57 \\
\hline 1930.3 & -13.40 & -3.64 & -1.90 & -6.58 & -4.19 & -2.61 & 1930.3 & -7.53 \\
\hline 1930.4 & -12.73 & -9.03 & -3.50 & -11.28 & -8.76 & -9.45 & & \\
\hline 1931.1 & -14.36 & -0.16 & 1.45 & -23.90 & -7.05 & -15.98 & 1931.1 & -8.88 \\
\hline 1931.2 & -21.22 & 3.86 & -5.11 & -4.88 & -3.52 & -5.35 & 1931.2 & -4.53 \\
\hline 1931.3 & -20.79 & -4.62 & -1.43 & 2.31 & 6.38 & 9.83 & 1931.3 & -3.93 \\
\hline 1931.4 & -18.04 & -4.22 & -0.37 & -13.82 & -11.93 & -3.45 & & \\
\hline 1932.1 & -21.05 & -0.18 & -1.18 & -10.26 & -6.70 & 2.36 & 1932.1 & -5.25 \\
\hline 1932.2 & -35.11 & -10.20 & -17.35 & 0.30 & -1.55 & 0.83 & 1932.2 & -6.06 \\
\hline 1932.3 & -21.77 & 9.50 & 9.74 & -1.57 & 3.24 & 7.03 & 1932.3 & -6.81 \\
\hline 1932.4 & -7.19 & 25.75 & 18.72 & -10.52 & -5.10 & -7.83 & & \\
\hline 1933.1 & -8.42 & 0.86 & 5.87 & -12.15 & -10.35 & -38.90 & 1933.1 & -5.55 \\
\hline 1933.2 & 9.31 & 8.03 & 18.97 & 17.63 & 18.90 & -5.24 & 1933.2 & 0.57 \\
\hline 1933.3 & 18.42 & 19.15 & 10.72 & 19.89 & 23.45 & 31.00 & 1933.3 & 17.31 \\
\hline 1933.4 & -8.07 & -5.27 & -17.50 & -27.07 & -20.72 & -8.57 & & \\
\hline
\end{tabular}


The source of the surprises was the large and continued negative shocks to the economy, against which policy makers took little action. The stock market crash of 1929 was contained and did not spread to the rest of the financial system because of the reaction of the Federal Reserve Bank of New York, but the decline in asset values reduced wealth. As Romer (1990) showed, households responded by reducing their consumption of semi-durables and dramatically their consumption of durables---products that required the intermediate goods shipped by the railroads. The banking panics and gold outflows reduced the money supply and the willingness and ability of banks to lend (Friedman and Schwartz, 1963; Bernanke, 1983; Eichengreen, 1992).

Business seems to have had considerable faith that either the business cycle would quickly turn or the Federal Reserve would take corrective action as it appeared to have done in the earlier recessions of the 1920s. As we know, the Fed certainly disappointed them. It kept to a strict adherence to the policies that had been developed in the 1920 s, using borrowed reserves and nominal market interest rates as policy instruments (Wicker, 1966; Brunner and Meltzer; 1968, Wheelock, 1991; Calomiris and Wheelock, 1998). When member banks borrowed little from the Fed and market rates were particularly low, policy was interpreted by the Fed as easy. The banking crises that made banks reluctant to borrow and the deflation that made real rates high rendered these instruments useless, ensuring the Fed would not respond.

While the Federal Reserve did not change its policy, business could not believe that the Fed would not react to the economic decline, leading business to incorrectly forecast the depth and duration of the depression. For the railways themselves, managers' animal spirits remained high, but at a cost, keeping inventories and their prices too high. The public and business were able to anticipate some of the deflation, with the consequence that real ex ante 
interest rates were extremely high. Yet, the collapse of demand and deflation were certainly not fully anticipated and thus business was left with excessive inventories and increasingly expensive debt burdens. 


\section{References}

Association of American Railroads, National Forecast of the Regional Shippers Advisory Boards (Washington, D.C., 1927-1941).

Bernanke, Ben S., "Nonmonetary Effects of the Financial Crisis in the Propagation of the Great Depression," American Economic Review 73 (June 1983), 257-276.

Bernanke, Ben S. and Mark Gertler, "Agency Costs, Net Worth, and Business Fluctuations," American Economic Review 79 (March 1989), 14-31.

Bonham, Carl and Richard Carter, "Testing the Rationality of Price Forecasts: A Comment," American Economic Review 85:1, (March 1995), 284-289.

Brunner, Karl, and Allan H. Meltzer, "What Did We Learn From the Monetary Experience of the United States in the Great Depression," Canadian Journal of Economics 1 (May 1968), 334-348.

Brunner, Karl, "Epilogue: Understanding the Great Depression," in Karl Brunner, ed., The Great Depression Revisited, Rochester Studies in Economics and Policy Issues, Vol. 2 (Boston: Kluwer-Mijoff, 1981), 316-358.

Calomiris, Charles W., "Financial Factors in the Great Depression," Journal of Economic Perspectives 7 (Spring 1993), pp. 61-86.

Calomiris, Charles W. and David C. Wheelock, "The Great Depression as a Watershed for American Monetary Policy." In Michael D. Bordo, Claudia Goldin, and Eugene N. White, eds. The Defining Moment: The Great Depression and the American Economy in the Twentieth Century (Chicago: Chicago University Press, 1998), 23-66.

Cecchetti, Stephen G., "Prices during the Great Depression: Was the Deflation of 1930-1932 Really Unanticipated?" American Economic Review 82 (March 1992), 141-155.

Dominguez, Kathryn M., Ray C. Fair and Matthew D. Shapiro, "Forecasting the Depression: Harvard Versus Yale," American Economic Review 78 (September 1988), 595-612.

Ehrbeck, Tillmann and Robert Waldman, "Why are Professional Forecasters Biased? Agency versus Behavioral Explanations." Quarterly Journal of Economics 111:1 (February 1996), 2140.

Eichengreen, Barry, Golden Fetters: The Gold Standard and the Great Depression, 1919-1939. (New York: Oxford University Press, 1992).

Evans, Martin and Paul Wachtel, "Were price changes during the Great Depression Anticipated?" Journal of Monetary Economics 32 (1993), 3-34. 
Federal Reserve Bulletin (1929-1941).

Fisher, Irving, "The Debt-Deflation Theory of Great Depressions," Econometrica 1 (October 1933), 337-357.

Ferber, Robert, The Railroad Shippers' Forecasts (Urbana, IL: University of Illinois Bulletin, Studies in Business Expectations and Planning, 1953).

Friedman, Milton and Anna J. Schwartz, A Monetary History of the United States, 1867-1960 (Princeton: Princeton University Press, 1963).

Granger, C.W.J. and Paul Newbold, Forecasting Economic Time Series (New York: Academic Press, 1977).

Hamilton, James D., "Monetary Factors in the Great Depression," Journal of Monetary Economics 19 (1987), 145-169.

Hamilton, James D., "Was the Deflation of the Great Depression Anticipated? Evidence from the Commodity Futures Markets," American Economic Review 82 (March 1992), 157-177.

Hultgren, Thor, The Allocation of Railroad Freight Cars (Chicago: NBER and University of Chicago, 1948).

Hultgren, Thor, "Forecasts of Railway Traffic," in National Bureau of Economic Research, Short-Term Economic Forecasting, Studies in Income and Wealth. Vol. 17 (Princeton: NBER and Princeton University Press, 1955).

Hylleberg, S., Engle, R.F., Granger, C.W., and Yoo, B.S. (1990) "Seasonal Integration and Cointegration," Journal of Econometrics, 44, Pg 215-238.

Keane, Michael P. and David E. Runkle, "Testing the Rationality of Price Forecasts: New Evidence from Panel Data," American Economic Review 80:4 (September 1990), 714-735.

Lovell, Michael C., "Determinants of Inventory Investment," in National Bureau of Economic Research, Models of Income Determination (Princeton: Princeton University Press, 1964), $177-232$.

Lovell, Michael C., "Test of the Rational Expectations Hypothesis," American Economic Review 76:1 (March 1986), 110-124.

Makridakis, Spyros, Steven C. Wheelwright, and Rob J. Hyndman, Forecasting: Methods and Applications $3^{\text {rd }}$ Ed., (New York: John Wiley \& Sons, 1998).

Moore, Geoffrey H., ed., Business Cycle Indicators (Princeton: NBER and Princeton University Press, 1961). 
"New Federal Reserve Index of Industrial Production," Federal Reserve Bulletin (August 1940), 753-795.

National Bureau of Economic Research, "Business Cycle Expansions and Contractions," www.nber.org.

Nelson, Daniel, "Was the Deflation of 1929-1930 Anticipated? The Monetary Regime as Viewed by the Business Press," in Roger L. Ransom and Richard Sutch, eds., Research in Economic History Vol. 13 (Greenwich: JAI Press, Inc., 1991), 1-65.

O'Brien, Anthony Patrick, "The ICC, Freight Rates, and the Great Depression," Explorations in Economic History 26 (1989), 73-98.

Patterson, K. (2000) An Introduction to Applied Econometrics: A Time Series Approach, Macmillan Press, London.

Pindyck, R.S and Rubinfield, D.L. (1991) Econometric Models and Economic Forecasts, $3^{\text {rd }}$ edition, McGraw-Hill.

Romer, Christina, D., "The Great Crash and the Onset of the Great Depression," Quarterly Journal of Economics 104, (November 1989), 719-735.

Romer, Christina D., "What Ended the Great Depression?" Journal of Economic History 52 (December 1992), 0pp. 757-784.

Romer, Christina D., "The Nation in Depression," Journal of Economic Perspectives 7 (Spring 1993), pp. 19-40.

Stover, John, American Railroads: A History (New York: Vintage Press, 1961).

Temin, Peter and Barrie A. Wigmore, "The End of One Big Deflation," Explorations in Economic History 27 (1990), 483-502.

Webb, Roy H., "The Irrelevance of Tests for Bias in Series of Macroeconomic Forecasts," Federal Reserve Bank of Richmond Econoic Review (November/December 1987), 3-9.

Wicker, Elmus, Federal Reserve Monetary Policy, 1917-1933 (New York: Random House, 1966).

Wheelock, David C., The Strategy and Consistency of Federal Reserve Monetary Policy, 1924-1933 (Cambridge: Cambridge University Press, 1991). 